\title{
Cathair Crobh Dearg: From Ancient Beliefs to the Rounds 2017
}

\author{
Frédéric Armao
}

University of Toulon, France

Copyright (c) 2017 by Frédéric Armao. This text may be archived and redistributed both in electronic form and in hard copy, provided that the author and journal are properly cited and no fee is charged for access.

\begin{abstract}
This paper will study the case of the stone enclosure of Cathair Crobh Dearg, Co. Kerry (also referred to as the City) and Dá Chích Anann (or the Paps of Anu), the twin mountains that can be seen from the enclosure. The site is mentioned in ancient mythological texts as well as more modern accounts in connection with the Irish festival of Bealtaine, in early May. The author relied on archaeological evidence, an analysis of ancient documents, a number of manuscripts from the Irish National Folklore Collection, as well as personal visits to the site in order to try and understand the nature, and possibly origin, of both contemporary rituals and ancient beliefs.
\end{abstract}

Key Words. Folklore, Mythology, Bealtaine, Cathair Crobh Dearg, Paps of Anu, Holy Well.

Resumen. En este artículo se investiga el recinto de piedra de Cathair Crobh Deargh, en el Condado de Kerry (también conocido como "The City") y Dá Chích Anann (o "The Paps of Anu"), las montañas gemelas que se distinguen desde dicho emplazamiento. El lugar se menciona en antiguos textos mitológicos así como en escritos más recientes en relación con la festividad irlandesa de Bealtaine, que se celebra a principios de mayo. El autor se basa en muestras arqueológicas, en análisis de documentos antiguos, en un número de manuscritos tomados de la colección del Folklore Nacional Irlandés, e igualmente en una serie de visitas al lugar en cuestión, con el objeto de intentar comprender la naturaleza y posible origen no solo de rituales contemporaneous, sino también de creencias ancestrales.

Palabras clave. Folclore, mitología, Bealtaine, Cathair Crobh Dearg, Paps of Anu, el Pozo Sagrado. 
In the eastern part of County Kerry ... and in the Barony of Magunihy - a barony being a subdivision of a county - there is an area known far and wide as Sliabh Luachra, the fertile or shiny hill. It is a rather quaint district, steeped in tradition, poetry and Gaelic literature. The focal point of this ancient area is, and has always been, a spot seven hundred feet above sea level, known as 'the City', or, to give it its correct title, Cromlech Cathair Crobh Dearg. If we break it down a little further it means, 'Red Claw's Mansion'! (Cronin 27)

Scientifically speaking, one may argue that the description made by Dan Cronin in 2001 lacks rigour. It is nonetheless precious as it conveys the emotional attachment many people still have to the place. Cathair Crobh Dearg or the City, Co. Kerry (5202'25.9'N / 9'15'21.7'W) retains a somewhat mystical quality: people continue to visit the stone enclosure and make the rounds at its Holy Well in the month of May.

The spiritual and traditional significance of the area cannot be fully understood without referring to its mythological relevance: from the enclosure of Cathair Crobh Dearg, two mountains (often qualified as holy by researchers and informants alike) can be seen, Dá Chích Anann or the Paps of Anu. The two twin mountains have been associated with the goddess (D)Ana / (D)Anu / (D)Anann (see infra) both in folklore and mythology for centuries, if not millennia. Each of the Paps is topped with a large cairn, clearly visible from Cathair Crobh Dearg, which emphasizes the distinctive breast shape of the two twin mounds, evidently echoed in their Irish and English names.

An ethnographic study of the site was carried on the first of May 2017, that is on the day usually referred to as Lá Bealtaine (anglicized May Day) in Irish tradition, as the site maintains a strong connection with this particular date and festival. 251 people visited Cathair Crobh Dearg on that day in 2017, many of which "made the rounds" (that is, they followed a precise circuit in and/or around the enclosure according to specific guidelines, the detail of which will be given infra), drank water from the Holy Well and performed a number of different rituals inside or around the enclosure, the details of which will be given infra.

First, a description of the site - which once again should be understood as including the subcircular stone enclosure as well as the two twin mountains that are visible from it, weather permitting - will be given: helpfully, a most valuable archaeological description of both Cathair Crobh Dearg and the cairns on the top of the Paps was published in 2006 by Frank Coyne. This paper will rely both on personal knowledge and experience (including a number of visits from 2003 to 2017) and the precious archaeological work of Coyne.

As mentioned before, the implication of the contemporary ethnological relevance of Cathair Crobh Dearg cannot be fully appreciated without a deeper understanding of the relevance of the Paps of Anu and the festival of Bealtaine in Irish and Celtic mythology: the most pertinent sources among ancient texts (that is, manuscripts written by Irish monks and scholars in the Middle Ages) will be mentioned. It should be noted however that, while describing pre-Christian culture, those texts are firmly situated in the historical and literary tradition of early Christian Ireland. Most researchers agree that the Christian monks did not simply transcribe the "original" pre-Christian myths: adaptations and changes - sometimes subtle, occasionally more radical - were made; the ancient tales arguably underwent a form of Christianization, even though how deliberate and conscious this Christianization was, we most likely will never know for certain.

Similarly, an overview of what is already known about the folklore of Cathair Crobh Dearg and Dá Chích Anann will be presented in order to detail and analyse the investigation carried out in 2017.

The purpose of this study is twofold. First, it may be interesting for future researchers to get a glimpse of what a gathering at Cathair Crobh Dearg, Co. Kerry might have looked 
and felt like in 2017. Furthermore, a complete account of the history of the site, in the broader meaning of the term (including a study and cross-analysis of archaeological, mythological and ethnographic evidence), does not seem to exist. This short paper could not possibly be as comprehensive; it might nonetheless represent a first step towards a fuller understanding of the site, its original significance and its evolution through centuries.

\section{Cathair Crobh Dearg and Dá Chích Anann}

Cathair Crobh Dearg, or the City in its anglicized version, can be found on Sliabh Luachra ("the Fertile" or "the Shiny Hill"), in the townland of Gortnagane, about six kilometres southwest of An Ráth Mhór (Rathmore), Co.Kerry, which is itself situated approximately twenty kilometres east of Killarney. The spelling of the site tends to vary, as often in an Irish context: Cathair Crov Derg, Cathair Chrobh Dearg, An Cathair Cubh Dearg (a spelling featured on a number of modern signs which were set up, funded and self-advertised as part of "the IRD Duhallow LEADER Programme 2007-2013 of the European Agricultural Fund for Rural Development"), Cathair Craobh Dearg and Cahercrovdarrig all refer to the same place, to mention but a few examples.

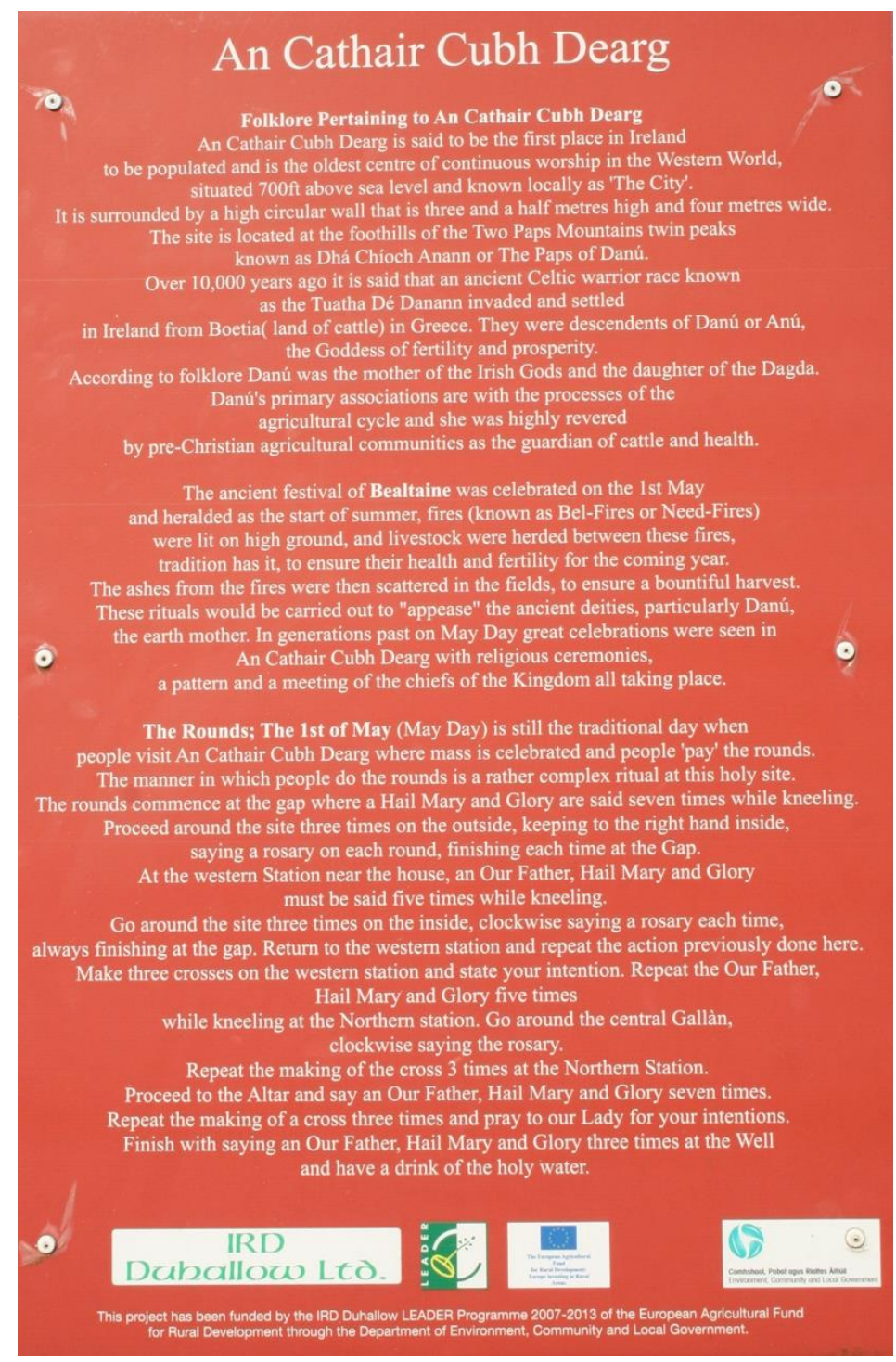

Fig. 1: The sign at the entrance of the site (Picture: Frédéric Armao, May 2017) 
The City in itself is technically not a single monument nor it is simply a circular or almost circular stone enclosure; the term Cathair Crobh Dearg includes the enclosure, which measures $52.0 \mathrm{~m}$ north-south by $48.0 \mathrm{~m}$ east-west (Coyne 46), the various structures and/or constructions within the site, as well as a path surrounding the stone enclosure. The thorough description made by Coyne is worth mentioning:

The enclosing element is best preserved on the eastern side of the site, where it attains a height externally of over $2.00 \mathrm{~m}$, where a distinct external batter is noted, the internal height averaging $0.75 \mathrm{~m}$. Here at east the wall is quite narrow, being approximately $2.50 \mathrm{~m}$ wide, although the wall is substantially wider at northeast, where it attains a maximum width of $4.30 \mathrm{~m}$. The site is currently entered through a broad breach in the wall at south, and also through a $1.00 \mathrm{~m}$ wide entrance at northwest, which may not be original. A second similar entrance at east, $1.70 \mathrm{~m}$ wide appears to have been in use at the time of the 1st Edition OS six-inch map and is more likely to be the original entrance. (46)
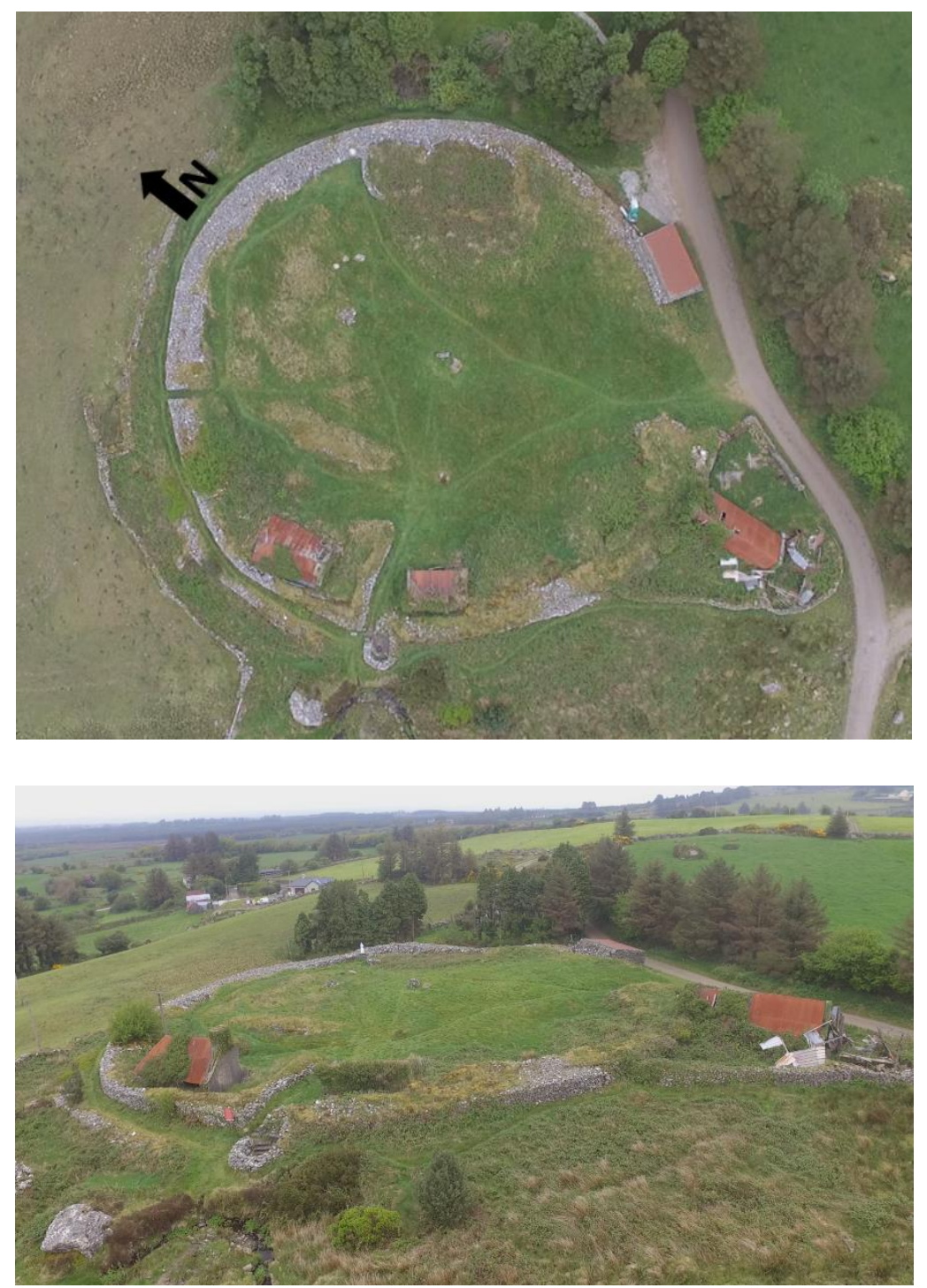

Fig. 2 (top) and 3 (bottom): Aerial views of Cathair Crobh Dearg (Picture: Frédéric Armao, May 2017) 
According to Coyne however, it appears that the site, which may initially have been a "large example of stone fort or caher/cashel ... has been extensively remodelled and rebuilt", most likely after 1895 (46). Coyne believes that this reconstruction may have coincided with the decline of the popularity of the pattern day, a day on which a patron saint was honoured. The local clergy seems to have been involved in the traditions at least as early as 1925 (Cronin 48); it may be possible to think that, on the contrary (or possibly in parallel to the lack of attendance to hypothetical pagan traditional rituals), the remodelling may have been part of an attempt to desacralize and then (re-?)gain control of a site that was too obviously pagan - as will be seen infra, other efforts to Christianize the site may have preceded this endeavour.

Inside the enclosure, two structures, a "house" and a "shed", are to be found - but were not mentioned in both the Ordnance Survey of 1841 and 1895, which implies that they were built afterwards. The house is now abandoned and in ruins. According to Dan Cronin whom I had the opportunity to meet and interview in 2004, it was inhabited as late as the mid$20^{\text {th }}$ century by the Quinihan (or Counihan) family, whose members also took care of the Holy Well of the City.

At the centre of the enclosure, two large rocks (or "megaliths") are visible, the first is $1.5 \mathrm{~m}$ long $\mathrm{E}-\mathrm{W}, 0.7 \mathrm{~m}$ wide and $0.7 \mathrm{~m}$ in maximum height; the second, "located 0.50 to the north, is orientated NNW-SSE on its long axis" $1 \mathrm{~m}$ high, $1.25 \mathrm{~m}$ long and 0.45 wide (Coyne 53). An excavation was carried out by Coyne in order to find evidence of a tomb: it did not prove successful. The archaeologist however hypothesized that the "upright stone was placed beside the bedrock, in order to form part of a chamber" and that originally, the two stones may have been covered by a cairn, now missing, and formed the top of a megalithic tomb. The covering might have gradually been removed over time, as a source of stone, maybe to build the aforementioned house or shed and/or consolidate the enclosure (Coyne 46-48). The stones are mentioned in the Ordnance Survey online maps, which indicate that the "Cromlech" was occasionally referred to as a "memorial stone"; there apparently used to be traces of ogham writings, now barely distinguishable, if at all, by the untrained eye (Ordnance Survey Ireland website 2017: Geohive map entity ID KE06598). Perhaps even more interestingly, charcoal was discovered during the excavation (dated 60BC-420AD) which demonstrates past activity on the site and is also not incompatible with what we know of some Bealtaine rituals (see infra).

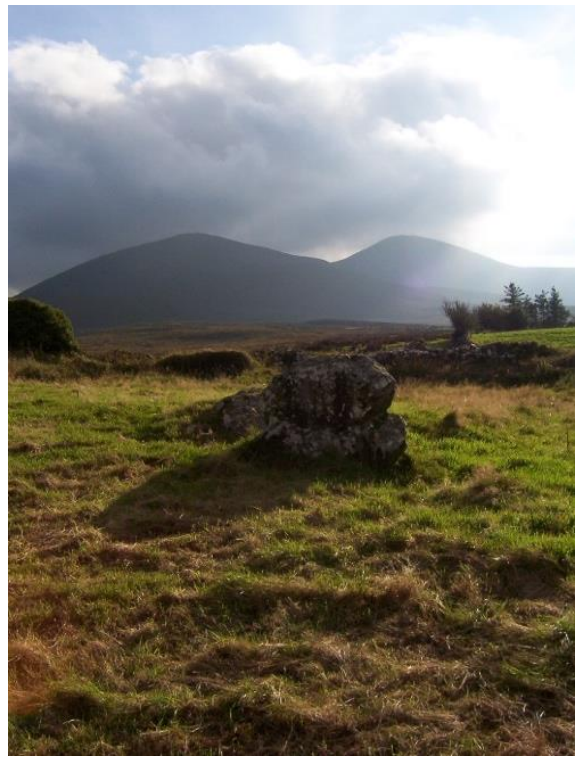

Fig. 4: The central stones, with the Paps of Anu in the background (Pic. FA, Nov. 2003) 


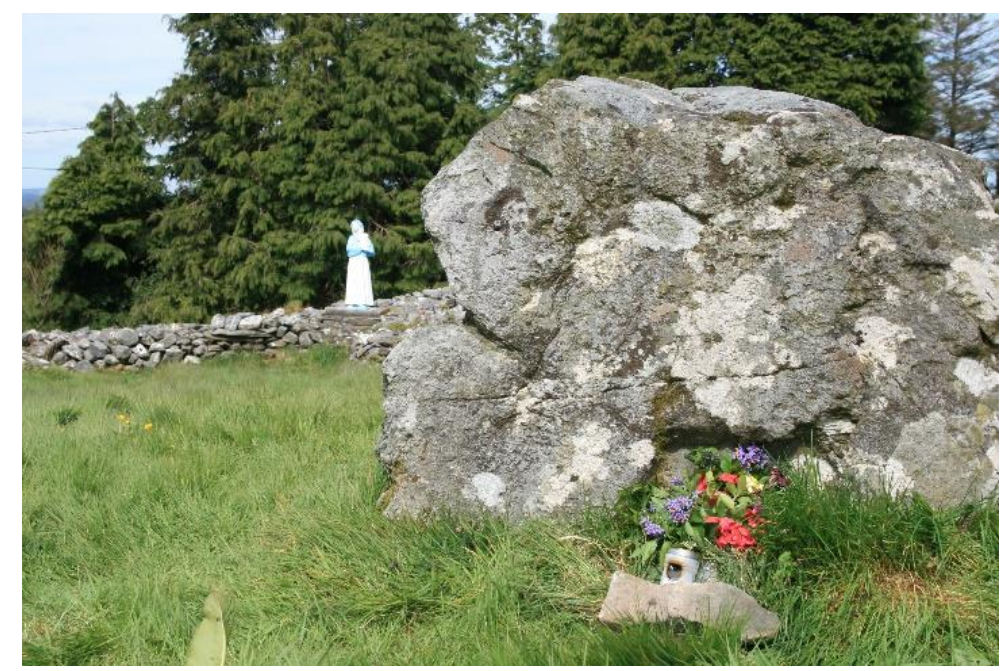

Fig. 5: The central stones, with the Altar in the background and small offerings (Pic. FA, May 2017)

To the northeast of the City, still inside the enclosure, a modern statue of the Virgin Mary was erected. At her feet, half a dozen flat stones are displayed; Celtic crosses are carved by pilgrims and visitors who pray and/or do rounds at the well. A number of manuscripts, including the ones which were collected by the Irish Folklore Commission in 1947 in relation to the festival of Bealtaine (NFC MSS. 1095 to 1097) and the Schools' Collection (NFCS 399-479 for Co. Kerry) mention that a statue was, or would be, erected in the 1930s (NFCS 453: 139, for example). Some versions even date back the construction of the altar of "Our Lady of the Wayside", as it is sometimes called, to the $13^{\text {th }}$ or even $10^{\text {th }}$ century (NFCS 441 : $251 ; 452$ : 34); the claim seems highly doubtful, to say the least, but indicates a wish on the part of the informants to inscribe this Christian tradition in the distant past of the island.

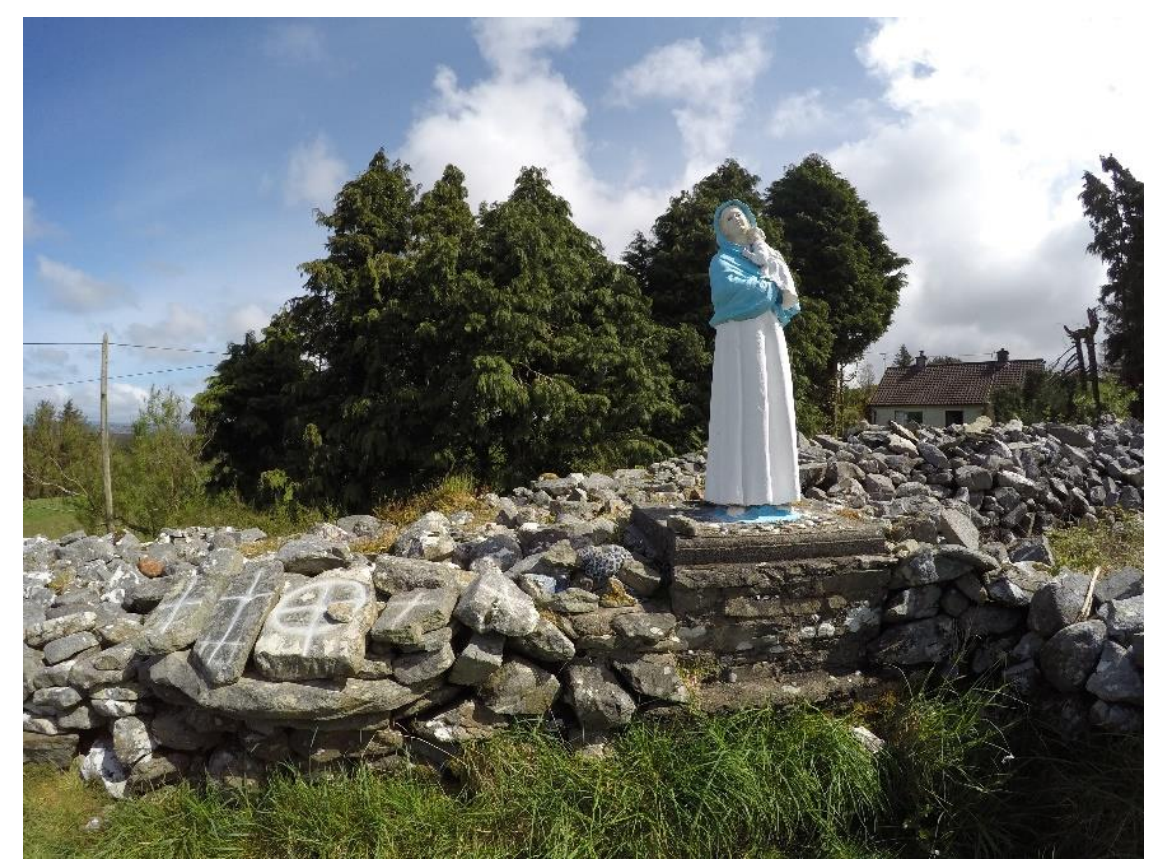

Fig. 6: Statue and altar featuring "Celtic crosses" (Pic. FA, May 2017)

Finally, apart from the various low mounds and partly buried cross-inscribed stones (used by a number of people as part of their rounds), the most important structure of Cathair Crobh 
Dearg is its Holy Well which lies on the western part of the site, immediately outside the enclosure, "inside a concrete pipe and modern enclosing Wall, although the original position of the well was actually further to the south" (Coyne 47). The Holy Well is sometimes called "well of Saint Crobh Dearg" (NFC 1095: informant 17; see infra).

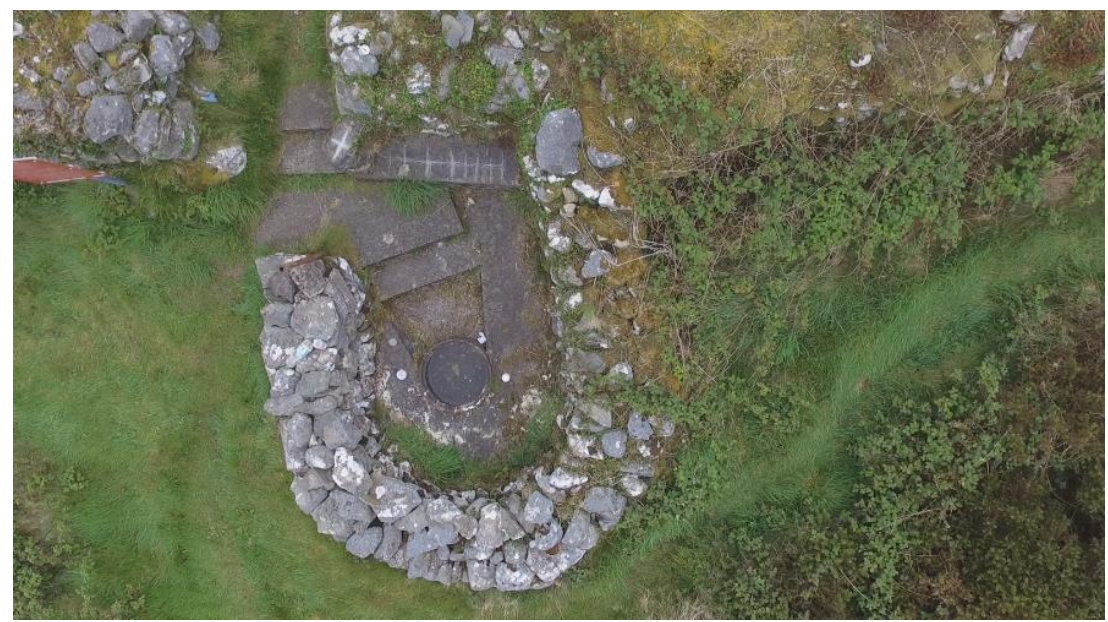

Fig. 7: Aerial view of the well with crosses carved on the concrete bench (Pic. FA, May 2017)

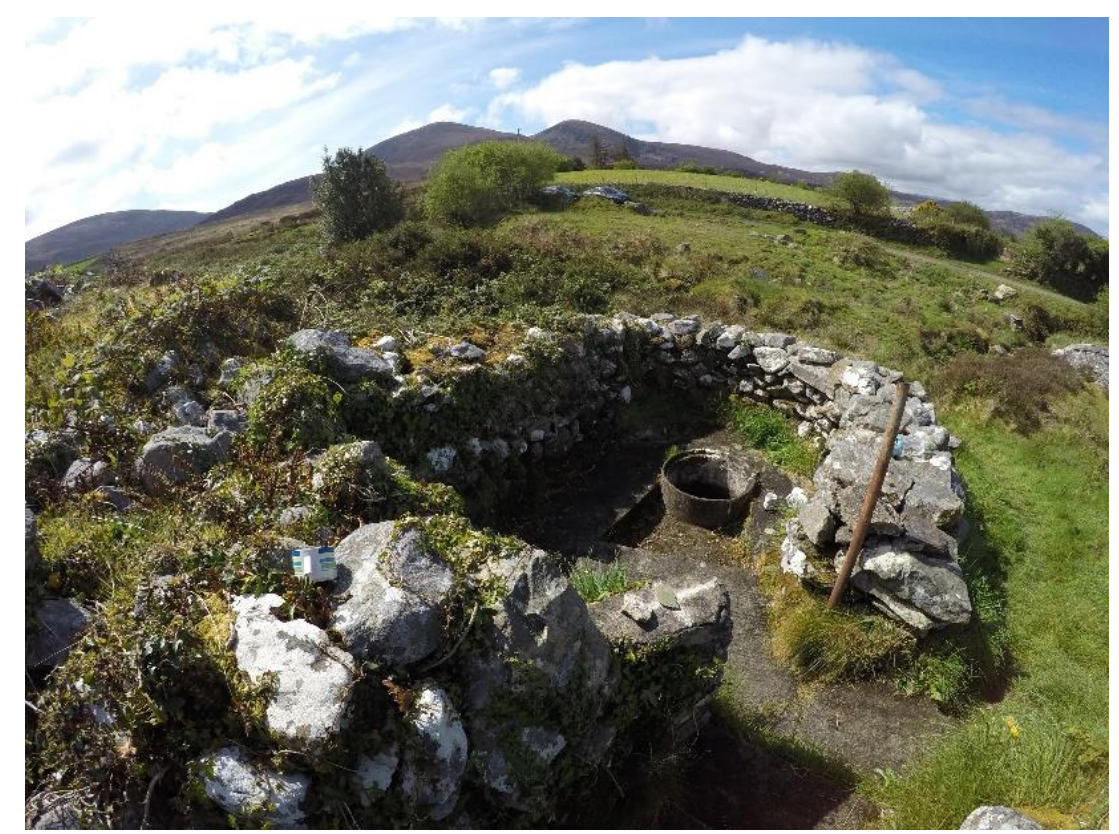

Fig. 8: Another view of the well with the Paps in the background (wide angle; pic. FA, May 2017)

Cathair Crobh Dearg can be entered through three passages: a breach at the northwest of the enclosing wall is called "the Gap" and is often mentioned in connection with the rounds; the west-south-west entrance is the one leading to (or coming from) the Holy Well; the widest (and today main) entrance is situated at the southeast of the site. When looking south, one cannot help but see the two overhanging mountains of the Paps of Anu and their two cairns.

Dá Chích Anann or the Paps of Anu form part of the Derrynasaggart mountain range. The twin mountains are of approximately the same height, with the western Pap rising to 690 meters and the eastern Pap slightly higher $(694 \mathrm{~m})$. They can be seen from around sixty kilometres away and, as expected, their obvious breast shape is clearly visible from the City, which lies on the northeast side of the mountains. Although from this angle they are easily 
identifiable, this distinctive figure turns into a somewhat irregular triangular form from a different perspective (for example from the northwest, the southwest or even when attempting to climb either one of the mountains).

The northern side of the Paps is used for rough pasture for cattle; the area surrounding the mountains also features "a considerable diversity of land use, including sheep grazing, turf cutting, [forestry] and also amenity, as both mountains are popular among hill-walkers" (Coyne 14). Although bordered by the popular Blackwater Way (a $168 \mathrm{~km}$ trail including the local Duhallow trail), the route to the top of either one of the Paps is not marked. The ascent from the City to the top of the eastern Pap is a two-hour climb, probably more for inexperienced walkers; it takes about one hour to go from one hilltop to another and the two tops are connected by an irregular and partly artificial line of stones referred to as "na Fiacla" (the Teeth), sometimes believed to have formed a processional route (Tempan 119), although no clear evidence can back up that claim.

The whole area surrounding the mountains has been thoroughly studied by Coyne. It includes a number of structures, ranging from stone huts, pre-bog walls, sheepfolds, an unclassified chambered mound and some fulachta fiadh (or burnt mounds, the function of which is still debated today among archaeologists), indicating local settlements dating back to the Bronze Age and possibly to the Neolithic Era (Coyne 34-42). However, the most emblematic and distinctive constructions are without a doubt the summit cairns on both peaks, which are believed to be the earliest monuments to have been constructed on or around the peaks.

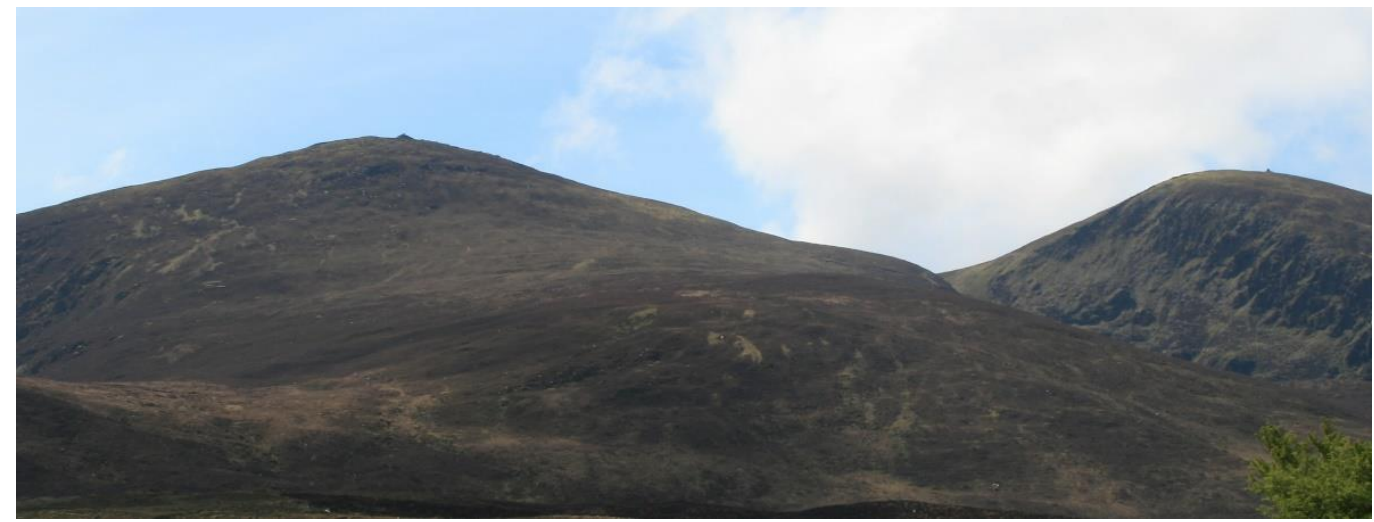

Fig. 9: The Paps of Anu (Dá Chích Anann); the cairns on the tops are visible(Pic. FA, May 2017)

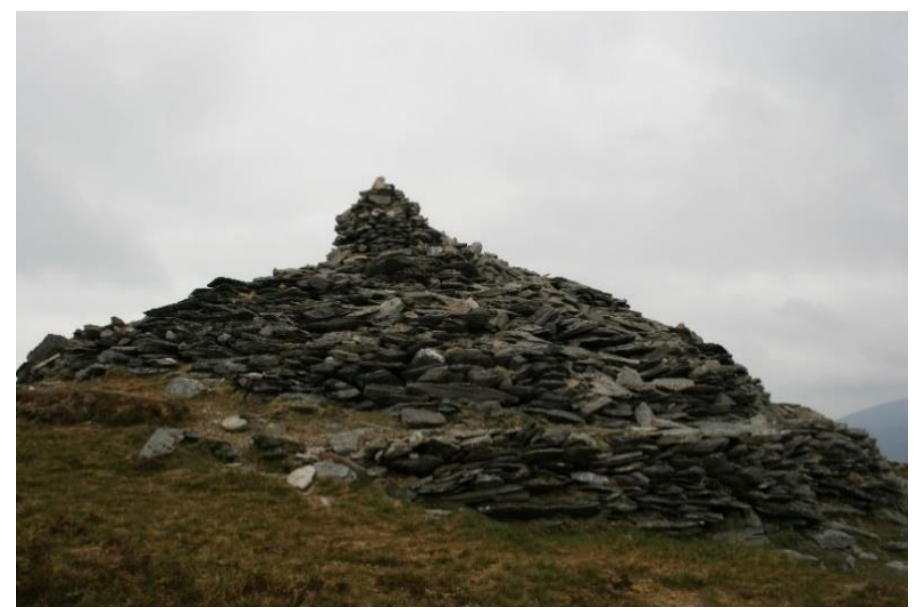

Fig. 10: Eastern cairn (Pic. FA, May 2017) 


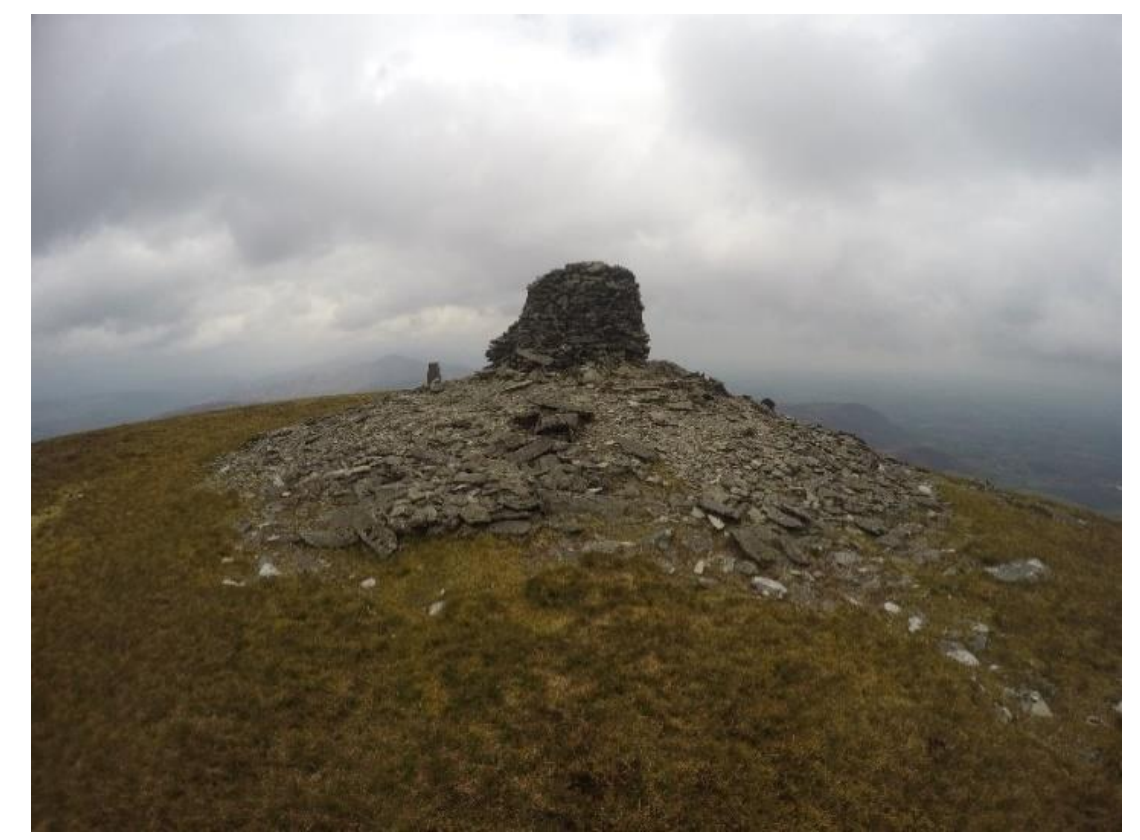

Fig. 11: Western cairn (Pic. FA, May 2017)

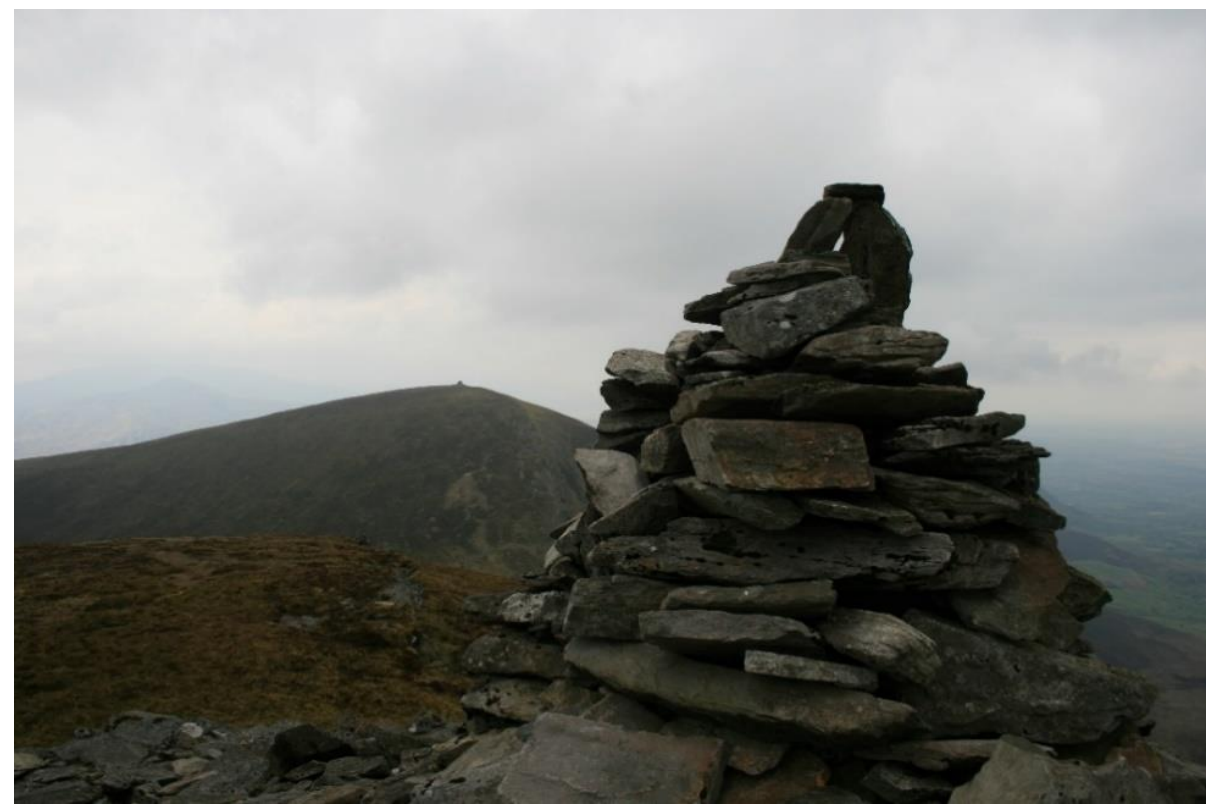

Fig. 12: Easter cairn, with view of the Western cairn in the background (Pic. FA, May 2017)

As Coyne notes, the placing of the cairns was deliberate "as neither sits directly on top of the mountain but over the crest slightly to the north, making them more clearly visible from that direction" (Coyne 52): Cathair Crobh Dearg is indeed on the north side of the Paps. Once again, Coyne provides a complete description of the two monuments (Coyne 41-5, 118 for the Western Pap, 22, 117 for the Eastern Pap). What should be remembered from this fascinating description is first of all the obvious will of the builders to shape and enhance the form of the mountains; the cairns, which are "not a haphazard dump of stones [but have a] complex construction which must have taken a considerable amount of planning" (Coyne 114), evidently bear the shape of nipples. This clear effort to anthropomorphise the landscape 
strengthens the symbolism of the breast: the sacred character of the site is beyond question. Superficial excavation of the western cairn in 2001 failed to prove the presence of a burial, although a more in-depth analysis would be required; the presence of a potential passage tomb covered by a stone cairn remains a plausible option to this day. The dating of those cairns is not clearly established, although archaeological evidence shows that they must have been constructed in the Neolithic Era or the Bronze Age. According to Coyne, it is even possible to suggest a "first act of monument construction ... sometime around 2,500BC" (Coyne 52), suggesting a pre-Celtic veneration of the place.

Of course, the full symbolic implications of the cairns at the top of Dá Chích Anann can only be appreciated if they are placed in the wider context of Irish myths and folk customs: if anything, the name of the mountains itself must be clarified.

\section{Ancient Beliefs: Myths and Folklore}

Dá Chích Anann translates to the "Paps of Anu", Anu standing for the goddess Ana/Anu or Dana/Danu. This etymology is already mentioned in the Lebor Gabála Érenn, whose first recession dates back to the $12^{\text {th }}$ century: "The Morrigu, daughter of Delbaeth, was mother of the other sons of Delbaeth, Brian, Iacharba, and Iuchar: and it is from her additional name 'Danann' the Paps of Ana in Luachair are called, as well as the Tuatha De Danann" (Macalister IV, 183; see also 103, 123-5, 155, 189 for other earlier versions).

Interestingly enough, Dana is sometimes said to be one of a triad of goddesses: "Badb and Macha and Anann [i.e. the Morrigu] of whom are the Two paps of Ana in Luachair, the three daughters of Ernmas the she-husbandman" (Macalister IV, 161). In the $17^{\text {th }}$ century, Geoffrey Keating, whose pseudo-historical statements must always be questioned, mentions that Dana also had three sons: "It is from [the] Danann, who was mother to these three [i.e. Brian, Iucharbha and Iuchar], Dá Chích Danann is called to the two hills which are in Luachair Deaghaidh in Desmond" (Keating 215). According to this interpretation, the name of Sliabh Luachra ("the Fertile or "Shiny Hill"), where Cathair Crobh Derg is to be found, would echo the name of one of Dana's son.

The notion of fertility is also reinforced by the etymology of Dana herself, meaning "good" or "wealth/abundance" according to some researchers (MacKillop 16) although a parallel with the word $d \bar{a} n u$, i.e. "stream" or "waters from heavens", is occasionally favoured - its root can be found in many stream and river names throughout Europe, including the Danube (Rees 53). As a consequence, Ana / Dana (if she is indeed one single goddess; see Green 30) would originally have been a goddess of prosperity. It is often said that Munster, where "she is adored" (Sjoestedt 24; Duval 56-57), owes its fertility to the "Mother-goddess of Ireland", a denomination first mentioned in Cormac's Glossary, most likely in the $10^{\text {th }}$ century: Ana, the "mater deorum hibernensium" whose association with the Paps of Anu is confirmed by Cormac, is said to "nurture the gods plenty" (Stokes, Three Irish 2). In that respect, further research including Ó Crualaoich's study of the Cailleach (the "hag" or "the Red Woman") might prove most useful, especially given the importance of both the colour red and the influence of witches in the context of either Bealtaine and Cathair Crobh Dearg (see infra; see also MacLeod and Lysaght).

The association of Ana/Dana with the mythical tribe of the Tuatha Dé Danann, is also interesting, to say the least. This paper is not the place to discuss those complex themes of Irish mythology. Let us however remember that the Tuatha Dé Danann were the mythical "tribe of Ana": according to a number of ancient sources, they are the gods of Ireland and are supposed to have to landed on the island for the first time in early May 
${ }^{1}$ and decided to set their ships on fire (Macalister IV, 139). The connection, in both modern and contemporary folklore, of Cathair Crobh Dearg and Dá Chích Anann to the Irish festival of Bealtaine, which is traditionally held in early May possibly stems from this mythological past.

Once again, this is not the place to mention and analyse all the ancient texts connected to Bealtaine; the festival, which has been associated in our modern calendar to the first of May, is one of the four ancient Irish festivals (Samhain, Imbolc, Bealtaine and Lughnasa). It marks the transition between spring (starting at Imbolc, in early February) and summer (lasting until Lughnasa, early August). According to sources dating at least to the $10^{\text {th }}$ century, it was a time when druids would light fires with "great incantations" (Stokes, Three Irish 6; Meyer, "The Wooing" 232); the cattle were driven between two fires in order to be purified and/or protected for the following year. It should be noted however that the etymology sometimes mentioned in ancient sources suggesting that the word Bealtaine stems from a hypothetical god named "Bel" (of which nothing is known, unless the debatable association with the continental Belenos/Belenus is accepted) and his fires ("Belltaine. i. bil tene.i. tene soinmech") is far from conclusive and is still debated today among scholars.

Bealtaine marked the start of the active part of the year, which lasted six months, as opposed to the passive season which lasted from Samhain (in early November) to Bealtaine; traditionally, a number of rural activities, including transhumance, started on Bealtaine. Witches and fairies were feared particularly at that time of year as they were thought to be wandering at night or early in the morning in order to accomplish miscellaneous mischiefs or cast evil spells, especially in connection with dairy products. As a consequence, a huge number of practices were performed so as to protect one's family and/or cattle for the following year: those rituals included, among many others, the use of fire/coal/embers/ashes, metal, water/dew, ribbons/flowers, adorned bushes/poles and more importantly visits to specific places, such as wells, lakes, hills or more rarely cemeteries (see Armao, "La Charnière" for a detailed account).

The connection with the fairies represent a large part of the folklore of Bealtaine; interestingly enough, they were sometimes associated with the Tuatha Dé Danann by Irish informants (NFCS 697: 352, "the fairies are the Tuatha Dé Danann”). In the context of Dá Chích Anann, the fairies are mentioned in a number of texts which, incidentally, are connected with Samhain, the other important time of the year where the supernatural beings could appear, as Bealtaine and Samhain marked the two moments when the gates between the world of the living and the Otherworld opened:

Fiacail told [Finn] to go and sit down by the two Paps of Anu, behind Luachair. So he went and sat down between the two strongholds which are between (?) the two Paps of Anu. Now, when Finn was there between them, on Hallowe'en night, he saw the two fairy-knolls opened around him, even the two strongholds, their ramparts having vanished before them. And he saw a great fire in either of the two strongholds; and he heard a voice from one of them, which said: 'Is your sweet food good?' (Meyer, “The Boyish” 187-8)

This excerpt shows a connection of the site to traditions much older than contemporary folklore, possibly with mythology (as fairies might be projections of either the Tuatha Dé Danann or the Fenians), which is in itself worth noticing: it is indeed very tempting to assimilate the two strongholds here mentioned to the cairns on the top of the Paps; the presence of a fairy in either one of the stronghold, associated with a great fire, also seems of great relevance and could be considered as an indication that at least one of the two cairns was designed as a burial monument. As Coyne states, "placing of burials within cairns created a 
direct link between the ancestors of the community that constructed the cairns and the sacred mountains" (Coyne 52); it should be remembered that the Tuatha Dé Danann are associated with both the fairies and the goddess Ana/Dana.

Finn is also mentioned, in connection with fairies, the Paps and Halloween (a common translation/adaptation of Oiche Shamhna, the eve/night of Samhain,) in another ancient text:

In revenge of the poet Orcbél

Finn slew Ua Fidga at a feast

in the west at the Paps, a brave achievement,

with the spear of Fiaclach, Conchenn's son.

(Meyer, "The Finn" 49)

As the feast here mentioned takes place "in the west" of the Paps, it may or may not be directly connected with the mountains. The mythological hero seems however to have chosen the Paps to kill his enemy for one specific reason: as mentioned in at least two texts dating back to the $14^{\text {th }}$ century, if someone was to "avenge their wrong" at the Paps of Anu "no retaliation was made upon him" (Stokes, “The Irish" 198-199):

'There are places where the slaying of a man is a vested right', saith Finn, namely, the highway of Midluachair, and the Ford of Ferdiad, the Ford of the Hurdles, the Gowran Pass, the Ford of Nó, the Wood of Bones, Conachlad, the two Paps of Anu in Luachair Dedad. Then Finn went to the two Paps of Anu, to compass the slaying of a man. (Meyer, "Two Tales" 244)

It is hard to completely understand why killing was not forbidden on the Paps without a thorough analysis of the text; it should be at least understood as yet another indication of the sacred character of the place.

One final document from the $12^{\text {th }}$ century is of great relevance in order to fully understand the nature of Dá Chích Anann and its connection with Cathair Crobh Dearg:

A journey I [Cael] have in hand on a Friday (if I go then am I a true guest) to Credhe's mansion (the effort is no trivial one) against the mountain's breast in the northeast. It is appointed for me to go thither: to Credhe, at the Paps of Anann; and that there I must remain exposed to difficulties, for four days and half a week. Pleasant is the house in which she is: what with men and boys and women, with both magicians and minstrels, with both cup-bearer and door-keeper, with both horsekeeper that never shirked his duty and dispenser to distribute meat, the command over all whom belongs to fair Credhe, the yellow-haired. (O'Grady 22; see also Murphy)

Once again, in-depth mythological analysis of documents such as these is not the subject of this paper. A crucial passage should however be noted: the mansion of Credhe, fairy lover of Cael (a Fenian hero) and daughter of the king of Kerry (MacKillop 110), is situated "against the mountain's breast in the northeast", the mountains being explicitly referred to as the Paps. It has been mentioned earlier that Cathair Crobh Dearg indeed lies on the northeast of the Paps and is the only remarkable structure of its kind there, with the exception of three sheepfolds and three small hut sites (Coyne 27).

This excerpt, which is, as far as I know, the only mythological source to link the two sites, therefore seems to provide proof of an ancient connection between Dá Chích Anann and 
Cathair Crobh Dearg. The fact that the daughter of a king of Kerry probably used the site as her "mansion" is not symbolically insignificant.

Cathair Crobh Dearg - still considered as "something of an enigma" in archaeological terms and whose date of construction "is also a matter of conjecture" (Coyne 49) - is usually translated as the "City of the Red Claws". In later traditions, a Saint Crobh Dearg(h) is mentioned, especially in connection with the Holy Well which is sometimes said to bear her name, as stated before. Some informants believe the City was constructed overnight by the Saint (of whom we know very little otherwise): her intent was originally to build seven walls but she was surprised by a man when she was erecting the fourth one. The man was holding a stick and halter; he had come there to steal a large red bull that was grazing nearby. Crobh Dearg fled and the man stole the bull (NFCS 441: 249-51; 452: 2; 453: 136; 456: 338, 348).

Tradition holds that the Saint had two sisters - therefore belonging to a triad of Saints, which could remind us of the famous triad of goddesses Ana/Macha/Badb of the Irish mythology. The two sisters were Saint Latiaran, whose holy well in Cullen was visited for Lughnasa (MacNeill 268-75; 578-582) and Saint Gobnait: her holy well at Ballyvourney was visited in early February, the date of Imbolc, yet another one of the four Irish festivals, (NFCS 452: 2; 453: 136, 231, 277; 455: 272).

Three saints, three holy wells, three Irish festivals: the connection between the various sites seems obvious and we cannot but regret that the original myth connecting the places - if it ever existed - was not passed down to us.

All three wells had the reputation to heal cattle and indeed the folklore of Cathair Crobh Dearg has been linked with the protection and/or purification of cattle and people for centuries; a number of beliefs relative to cattle are explicitly mentioned by informants in the Schools' Manuscript Collection (mainly NFCS 441 and 452). It was believed that the City could hold an almost infinite number of cows at Bealtaine: no matter how numerous the farmers and cattle would be, it was impossible to fill the enclosure of Cathair Crobh Dearg. According to tradition, the first holy well was actually inside the enclosure (and, as a matter of fact, archaeological finds proved that the current well is a modern one); one day, a bull is said to have drowned in the old well and it was decided to fill it up: the current well then sprang and although it was not as deep as the previous one, it kept its potential to protect cattle (NFCS 441 and 452).

The main custom connected to the site was the "driving of cattle" to the well. In ancient times the cattle were, throughout Ireland, driven between two fires on Bealtaine to protect them from diseases and spells for the following year. Comparable instances are found in the modern (yet not contemporary) folklore of the surroundings of Cathair Crobh Dearg. ${ }^{2}$ For the same reasons, cattle were taken inside the enclosure of the City so they could drink the water of the well on Bealtaine. The cattle were occasionally left there during the night before Bealtaine (Cronin 41). The first mention of the custom, which apparently died out at the beginning of the $20^{\text {th }}$ century, dates back to the Ordnance Survey of 1841 (O'Donovan 95). The belief in the curative/protective effect of the water of Cathair Crobh Dearg for both animals and people was common and, as will be seen in the last part of this paper, still exists today. According to one informant, the water could keep its effect for a whole year and was efficient against all diseases of men, cattle and horses alike (NFCS 452: 33); other informants insist on the fact that it was only effective if collected in the first hours of Bealtaine (NFCS 456: 293) or that it should be kept within the family and never given to strangers (NFC 1095: 17), when others believed it had to be shared (NFCS 452: 216). Finally, a rather specific - and evidently Christianized - version of the custom was also mentioned in 1896:

The operator, who is generally the person who performs the pilgrimage, first commences with the oldest [animal] after which he next takes the youngest, be it cow 
or heifer, or even weaning calf; after which all the others are treated indiscriminately. Armed with a teaspoon, he first drops three drops into her right ear, after which three similar drops are dropped into her mouth; the invocation in each instance being the usual one, 'In the name of the Father, and of the Son, and of the Holy Ghost. Amen'. (Collective II, 318)

The Christianization of the site occurred gradually and peacefully, as often in an Irish context (Maignant 13-20). Although no official and specific date can be put forward, it is worth noticing that many priests preached sermons at the City in May as early as the 1920s; for instance, in the first hours of May Day 1925, a certain Father William Ferris claimed:

The pagan danger is now past. Paganism is dead, or rather all the best elements in it have been absorbed into Christianity. It would therefore be criminal negligence on our part to allow this storied stream of age-old enthusiasm to perish ... It is most fitting that the Festival is held on the first day of Our Lady's month, for the Mother of God, in the person of Dana, has been worshipped here for hundreds of generations. (Cronin 48-8; see also NFCS $441 \& 457$ for other sermons)

The assimilation of Dana to the Virgin Mary was most fitting, and might explain why the site was officially dedicated to the mother of Jesus. May is also the month of Mary in the Christian tradition, which most likely helped worshippers to accept the Christianization of their beliefs and rituals. Additionally, the fact that Mary is an emblem of Catholicism as opposed to Protestantism should not be underestimated. This specific form of Christianization, or at least well thought-out clerical involvement, may echo a quest for a renewed identity in the peculiar, changing times of the independence of Ireland (Armao, "Le pèlerinage"); it must be remembered that the statue of Mary was most likely erected in the late 1930s, even if the association with a specific female saint (i.e. Saint Crobh Dearg) may indicate an even earlier attempt to Christianize the site.

Finally, there apparently used to be a popular joyful celebration at Cathair Crobh Dearg which, on Bealtaine, seems to have been a "hubbub of activity", at least as early as the $19^{\text {th }}$ century:

The music of pipes and fiddles re-echoed from the hills and valleys, and the lowing of cattle mingled with the sweet music of the harp. Jesters and jugglers plied their respective trades, with everybody trying to make themselves heard. It is very evident that ale was brewed here in plenty. Champions were performing feats of valour while throngs of admirers looked on. All of the aforementioned activities were enacted right up to the restrictions brought about by the outbreak of World War II, as a result of which nothing but the religious side remained. (Cronin 38; see also NFCS 456; NFC 1095: inf. 5 and 6)

However, as time passed and as Christianization went on, the festive gathering died out; a priest of the parish apparently even denounced the "over-indulgence" in alcoholic beverage at the City at the end of the $19^{\text {th }}$ century (Cronin 2001: 41). It is hard to date the last organisation of the festive assembly, although Cronin mentions the Second World War. On the first of May 2017, when asked, at least three visitors remembered attending such merry gatherings as a child; they included "many people" having fun, dancing, drinking, gathered among a number of "vending booths" and unspecified "attractions", at least as late as the late 1950s (one informant talked about "massive attendance" in 1958-9). 


\section{Cathair Crobh Deargh 2017}

This study of the visits to Cathair Crobh Dearg on the first of May 2017 confirms that nowadays no joyful celebration or gathering takes place. Similarly, no lighting of fire whatsoever happened on that day, contrary to what might have been expected in the context of a Bealtaine gathering. No fire or bonfire either within the enclosure of Cathair Crobh Dearg or at the top of the Paps of Ana were lit. Similarly, no cattle were driven within the enclosure; two distinct cow herds passed by the site on that day and the farmers did not make them drink at the well. It does not mean however that cattle are never driven to the site. For instance, a picture featured on the software Google Earth (https://www.google.com/earth/), which displays satellite views of Earth, clearly shows several cows entering Cathair Crobh Dearg (although the satellite picture was taken in April 2013, not on Bealtaine). It was sometimes hypothesised that originally, cattle were taken to the Paps, between the two mountains, at the pass occasionally referred to (for obvious reasons) as "the cleavage"; a fire would have been lit at or by the cairns and the animals were driven between the two fires; they were supposed to walk through the pass to be purified or protected for the following year. A visit to the top of both Paps and at the "cleavage" on the fourth of May 2017 leads us to refute the hypothesis: the climb would be too long and hard for cattle; the nature of the soil at the "cleavage" is also too impractical for such rituals: the boggy terrain occasionally turns into ponds of water. A larger pond, which is almost exactly situated at the centre of the "cleavage" and should be investigated for potential offerings, creates a brook and, when it rains, gives birth to quite a sheer waterfall flowing north, making it impossible for cattle to go through the pass in its entirety.

The present investigation at Cathair Crobh Dearg started at 8AM on Monday, the first of May, and the first visitors came after almost three hours of waiting: a man in his eighties, accompanied by his son, arrived at 10:45. They both remained on site for about thirty minutes. They first walked around the enclosure of the City clockwise while quietly uttering prayers, then went inside and prayed in front of the statue of the Virgin Mary; after a couple of minutes, they went to the holy well and used a stone to carve the sign of the cross three times on the concrete bench facing the well (see aerial picture of the well), then again with their finger; they made the sign of the cross on their forehead and proceeded to drink the water and gather some in a plastic bottle, which they took with them. Finally, they went out of the enclosure of the well, leaving the site behind them, and made one last prayer while looking at the Paps, therefore confirming the connection between the stone enclosure and the two mountains.

A more or less official manner of doing the rounds (Irish: turas) exists: it was mentioned by Dan Cronin and a version is featured on the sign at the entrance of Cathair Crobh Dearg (dated 2013, see supra):

1. Commencing at the Gap [the northwest entrance]: Our Father, Hail Mary and Glory, said seven times while kneeling.

2. Go around The City, three times on the outside, deiseal (keeping the right hand inside). Say a Rosary on each round, finishing each time at the Gap.

3. At the western Station, near the house, say Our Father, Hail Mary and Glory, five times, kneeling.

4. Go around The City three times inside, clockwise, saying a Rosary each time, always finishing at the Gap.

5. Repeat (3), then make three crosses on the western Station, with a pebble or with your finger, mentioning your intention. If for yourself, rub the dust on your forehead. 6. Repeat (3) again, this time at the northern Station. 
7. Go around the central Gallán [standing stone], clockwise, saying the Rosary. 8. Repeat (5) at the northern Station.

9. Go from northern Station to the Altar at the eastern side, saying a decade of the Rosary.

10. At the Altar say Our Father, Hail Mary and Glory seven times. Repeat crosses as at (5), also circle. Pray to Our Lady for your intentions.

11. Say Our Father, Hail Mary and Glory three times at the Well. Have a drink of the water and take some with you. (Cronin 42-3)

Not one single person did the rounds according to this complex method on Bealtaine 2017. Most of the time, people willing to do the rounds simply walked around the enclosure clockwise, prayed in front of the statue of the Virgin Mary and drank at the well, occasionally filling up bottles (sometimes up to a dozen) that they took home and would use as "holy water" to protect or cure either people or cattle. Only one person was seen kneeling and, interestingly enough, the man first kneeled in front of the statue of Mary and later in front of the abandoned shed within the enclosure (two candles had been lit and placed inside the shed before 8AM, most likely on the previous day).

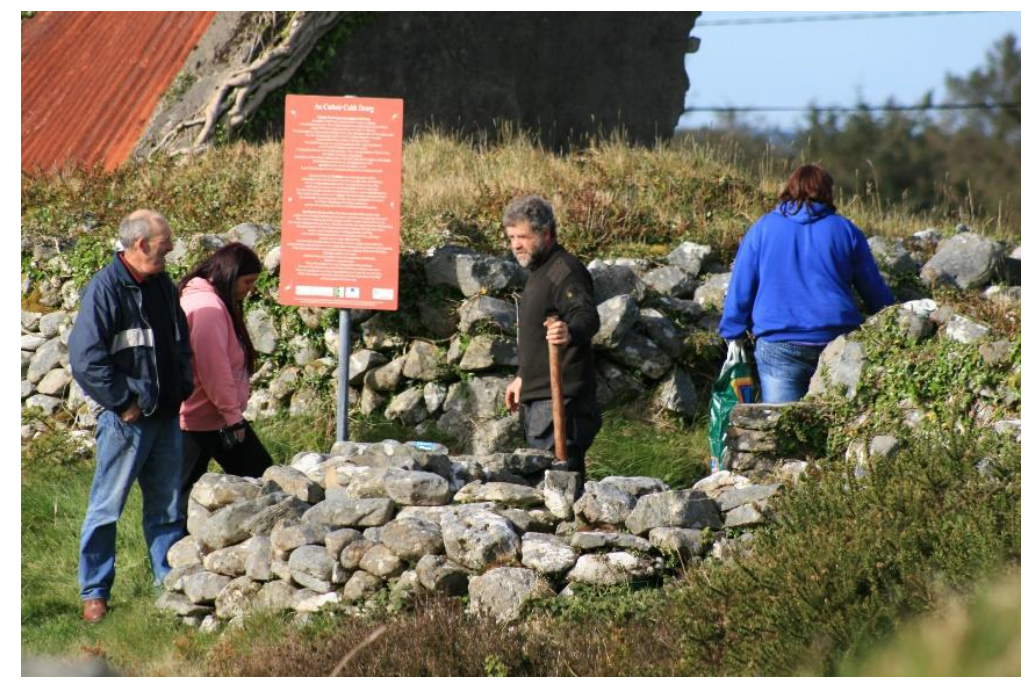

Fig. 13: People visiting the well (Pic. FA, 1 May 2017)
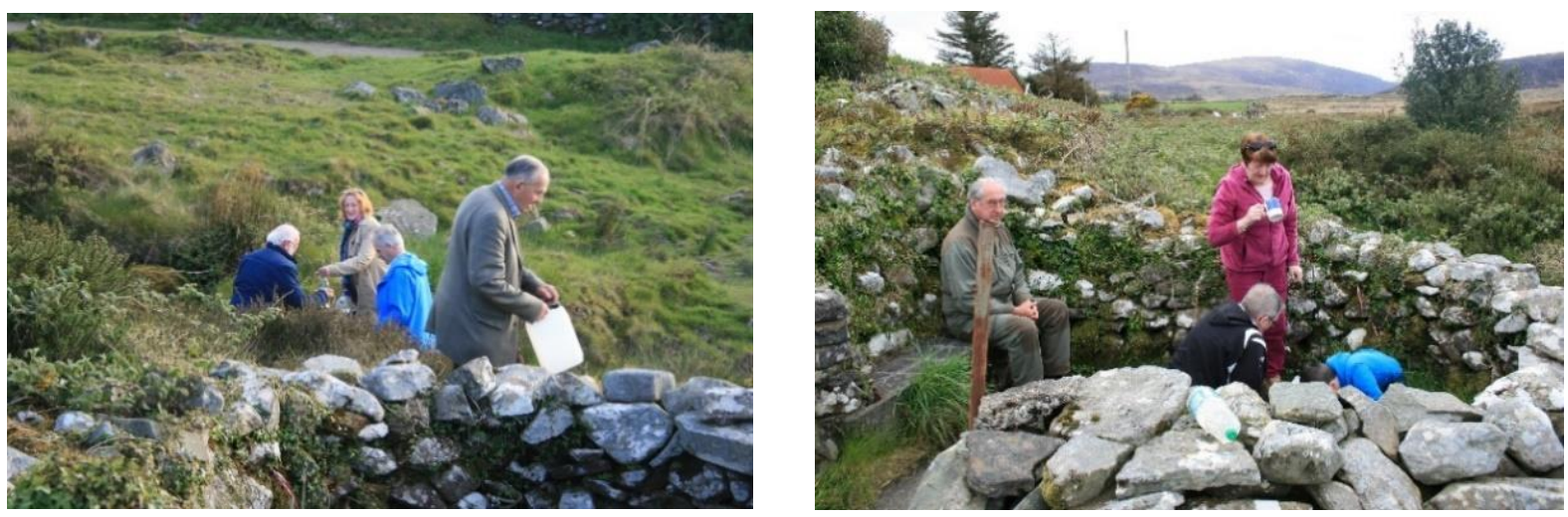


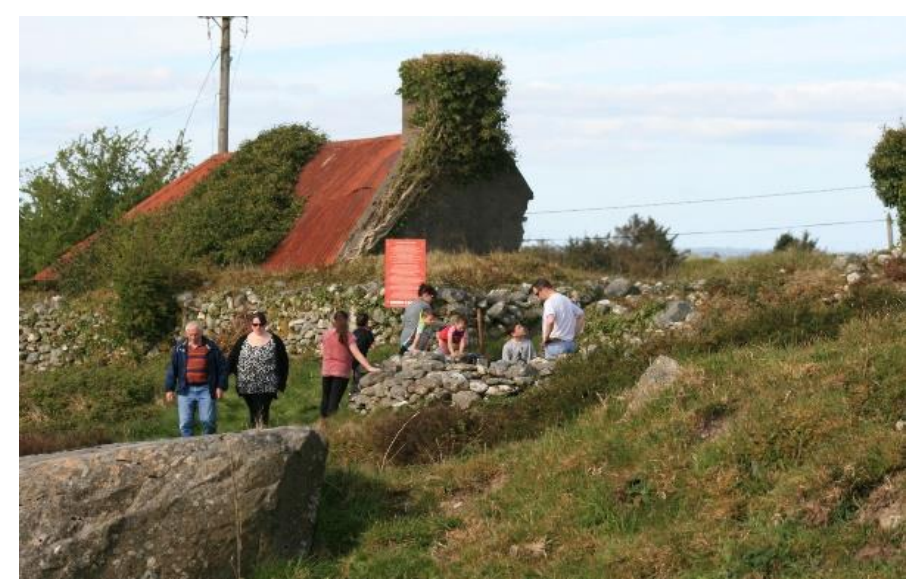

Fig. 14 (top-left), 15 (top-right), fig. 16 (bottom) People drinking water and filling up bottles at the well (Pic. FA, 1 May 2017)

Most visitors prayed, sometimes for a very long time - up to two hours - and did the rounds in their own ways: both the statue of Mary and the Holy Well seemed to be the centre of attention, although some visitors used the central stone as a part of their rounds. In that case, they would sit or lean on the standing stone while praying and looking at the statue. Some people used a rosary when praying and stopped at each "station", i.e. semi-buried rocks on which a cross had been carved. However, most visitors ignored the stations, probably in part because some of the cross-inscribed stones were covered in weeds and were virtually invisible. As a matter of fact, the site does not seem well looked after, a large portion being covered in wild grasses and the house and shed being half in ruins, which was not the case when I visited the site in the previous decade. The statue of the Virgin Mary, on the other hand, is clean and the paint looks fresh: some visitors claimed that it had been vandalised " $\mathrm{a}$ couple of years ago" and that it had been replaced.

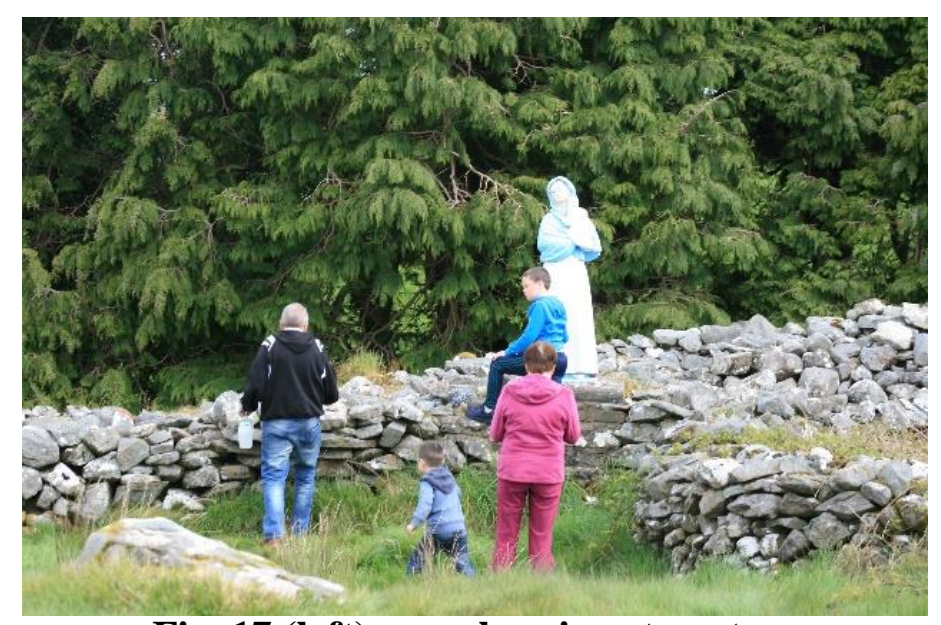

Fig. 17 (left): people using stone to carve

crosses while holding a bottle

of water from the well 


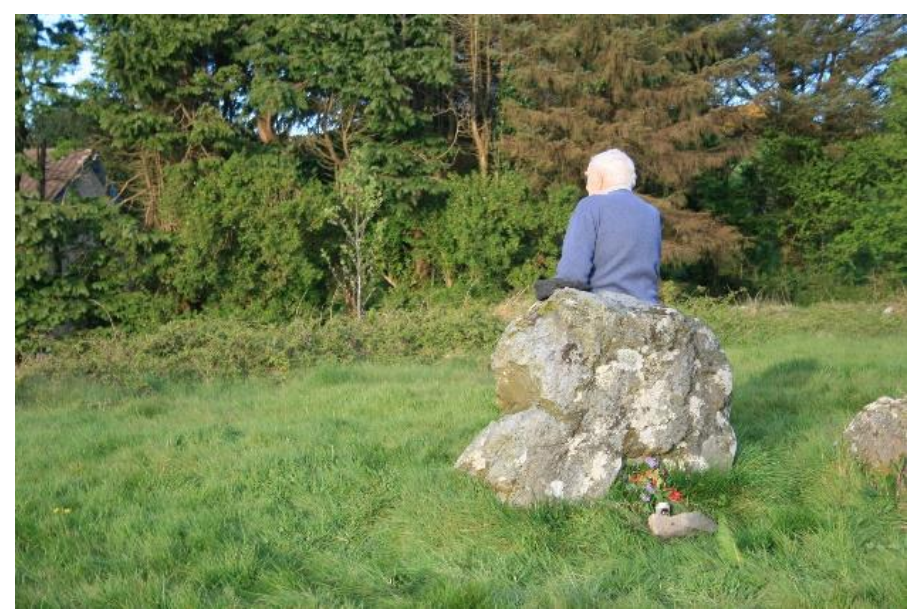

Fig. 18 (right): man praying, looking at the statue of Mary while sitting on the central stone

(Pic. FA, 1 May 2017)

On the first of May 2017, the well itself gradually dried out until there was no water left at around 6PM, which according to a number of (quite infuriated) visitors was "a first". When seeing that the well was dry, some people simply turned their back and went home, when others anxiously asked whether or not the water of the little stream flowing a couple of meters next to the City was the same as the water of the holy well; they then proceeded drinking or taking water from that brook.
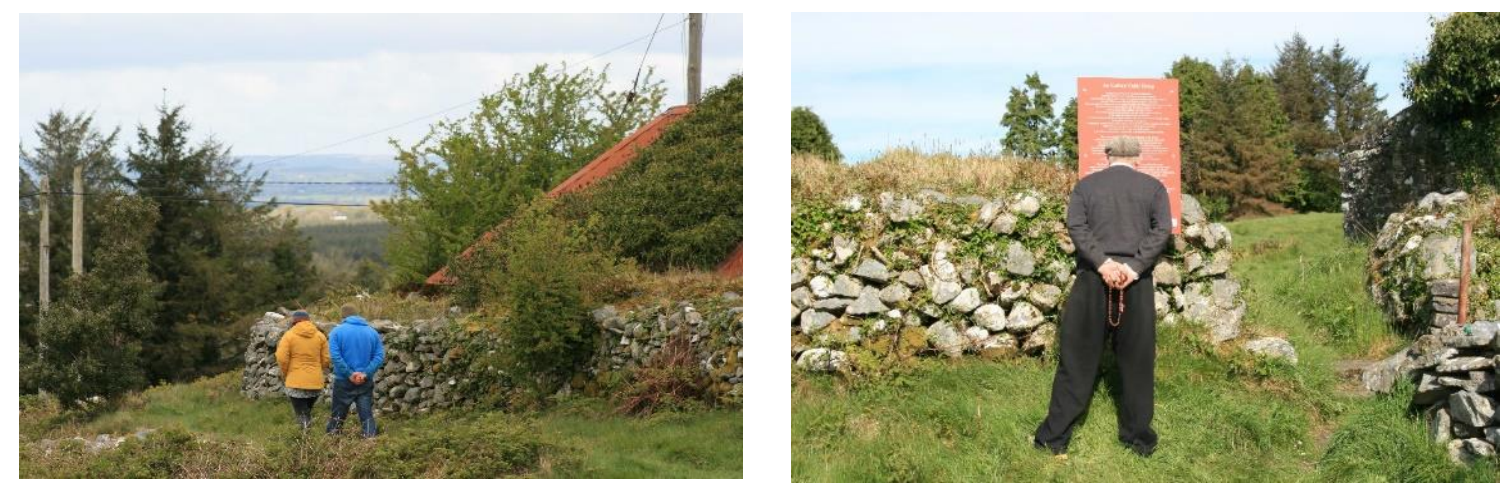

Fig. 19 (left): couple walking around the enclosure Fig. 20 (right): man reading the sign before doing the rounds while holding a rosary (Pic. FA, 1 May 2017)

People visited Cathair Crobh Dearg for various reasons. Most visitors wore casual clothes, with the notable exception of three men (one in the morning, the other two in the late afternoon) visibly wearing their Sunday clothes (even though the first of May 2017 was a Monday) and some hikers in their sports outfit. Indeed, some people only entered the enclosure to spend some time there as mere observers: a number of hikers simply passed through and watched people doing their rounds. Many families came to spend some "quality outside time" with their children, talking and enjoying the peacefulness of the place. Some of them (mainly grand-parents) explicitly mentioned they wanted to show the "old ways" to their grand-children and pass on the tradition. In this regard, it must be remarked that the average age of the visitors was well above 50, two-thirds of the visitors being visibly 50 or older, as shown in the tables below: 


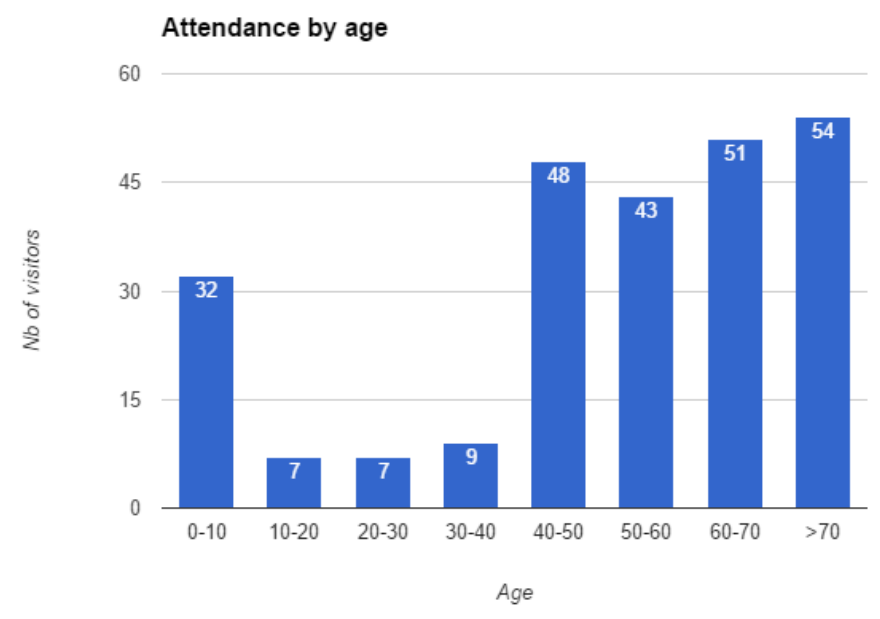

Fig. 21

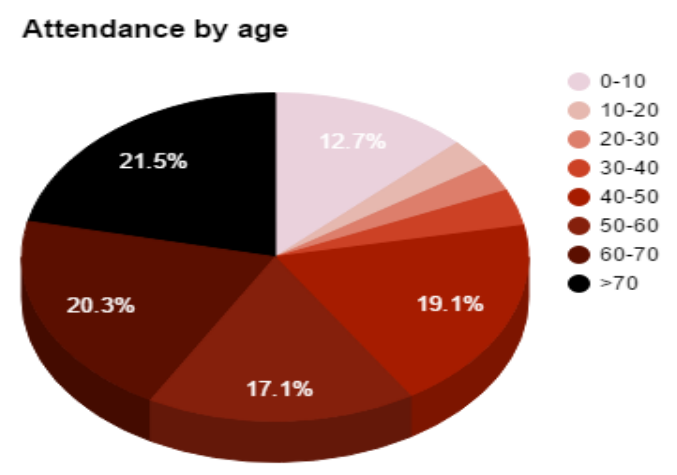

Fig. 22

32 children under 10 were brought to Cathair Crobh Dearg by their family and only 14 people out of 251 visitors were between 10 and 30; it may be argued that the nature of the traditions - quiet, rather undramatic prayers and rounds - do not necessarily appeal to younger generations.

A majority of visitors were locals, men and women alike (the gender balance was almost perfectly respected with 125 women out of 251 visitors). Almost all visitors belonged to what may be referred to as the "white Irish" ethnic group, with the notable exception of two young women who were visibly of Asian descent, which came as a surprise - and perhaps a little more - to some locals. Most people came from Co. Kerry or the neighbouring Co. Cork. A number of visitors had been driving from various counties of Éire; a precise list was not established but some of the people that I met came from (or knew people that had come from) Co. Dublin, Co. Waterford, Co. Offaly and Co. Wicklow, which indicates that the popularity of the City, though by no means as great as that of Uisneach for instance, still goes beyond the limits of the local parish. 


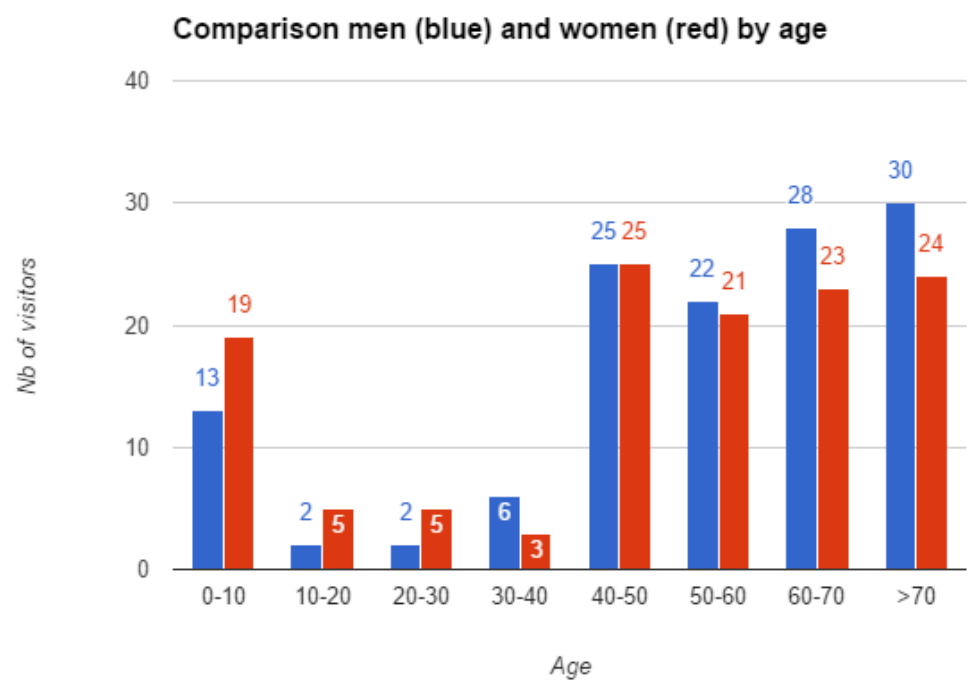

Fig. 23

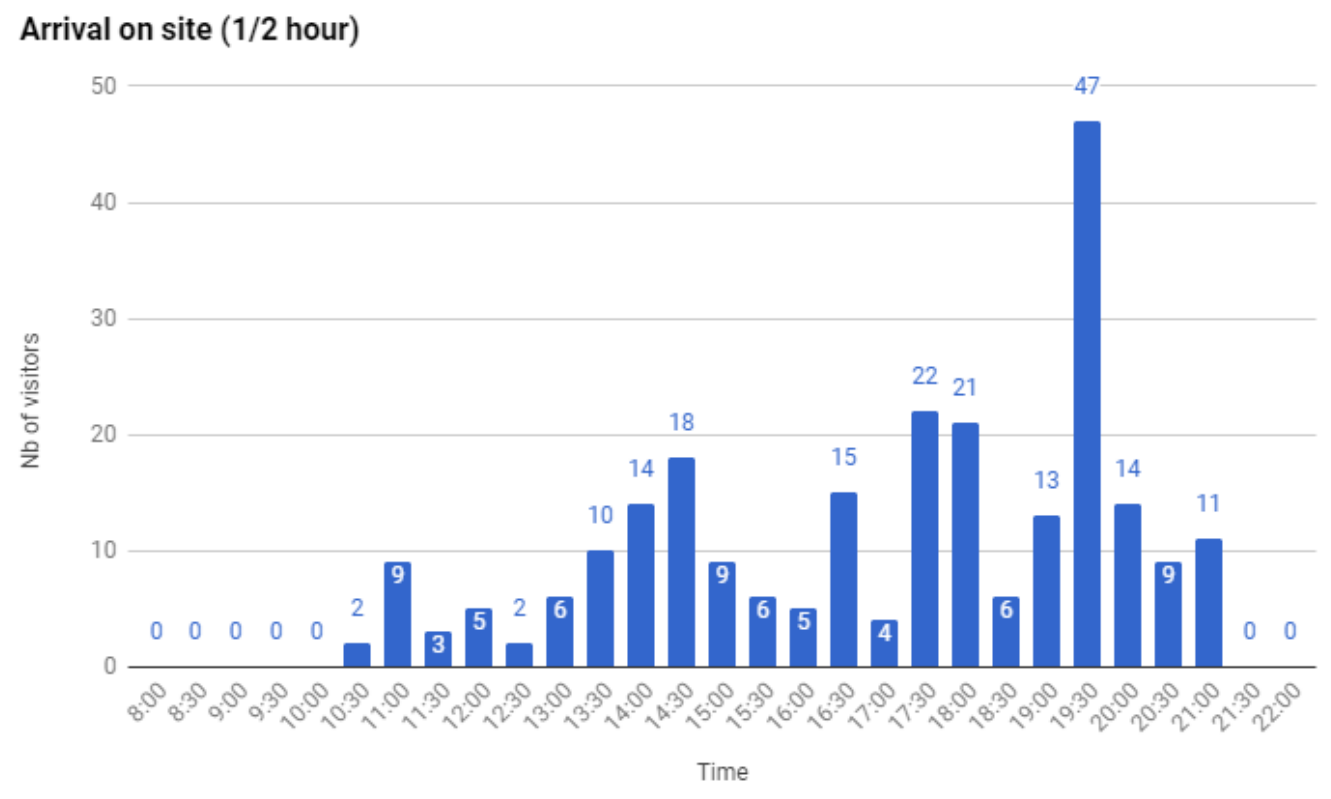

Fig. 24

Originally, the investigation on site was supposed to stop a little before sundown: since older traditions held that Cathair Crobh Dearg should be visited early in the day, it felt unlikely to witness people visiting the site after 7 or $8 \mathrm{PM}$, which was a huge misconception, to say the least. Almost $40 \%$ of visitors (94 people) came after 7PM; as far as can be told, the last people arrived at 9:25PM.

After over fourteen uninterrupted hours of on-site study, the investigation was stopped at 10:05PM, leaving a total of six people still gathered at the well, two of which had arrived over an hour before, when it was not completely dark yet. One of the women who was still there had previously been sprinkling water on the central stones, after a long prayer to Mary; some flowers and a lit candle had been put at the foot of the stones. Other offerings (including ribbons, flowers, letters and small objects with little or no monetary value such as plastic necklaces or old scarves) had been placed on the altar next to the statue of Mary.

A number of beliefs or rituals were mentioned and discussed by visitors during the day: a couple of informants assured that people still climbed the Paps on Bealtaine or the first 
days of May to leave offerings on the cairns; although there is no reason to question this statement, a visit to the Paps on the fourth of May failed to confirm it, as no offering was found. According to others, a mass is usually held on the Sunday before (or following) Bealtaine in the enclosure of Cathair Crobh Dearg, "weather permitting"; no one was met on the previous day, that is Sunday evening, the $30^{\text {th }}$ of April 2017 (a presence on site was maintained from 6PM to 9:30PM), which may be explained by the bad weather or the late hour. On the first of May 2017, two visitors excitedly talked about the cuckoo, which they had heard singing earlier in the day; that piece of information was welcomed with enthusiasm by the people listening to the conversion because it was "a sure sign that summer [would] be coming in a couple of weeks". The belief in the symbolic importance of the cuckoo in the context of Bealtaine is common: many people do mention proverbs and similar beliefs in various manuscripts (NFC 1095: inf. 1, 4, 6; NFC 1096: inf. 77, 115, 144; NFC 1097: inf. $183 . .$. ; see also DeBhaldraithe 82-3 and 136).

As a whole, the most striking feature may be the general atmosphere of the place. When entering the enclosure or coming close to the well, most people began talking in a softer voice or even chose to remain silent: it is evident that Cathair Crobh Dearg is considered by many as a form of open-air place of worship; the prayers recited were merely whispered, the rounds carefully and cautiously executed. A fifty-year-old man even firmly told his mother, who was well into her eighties, to take her hands out of her pockets to "show some respect" to the place, which is quite symptomatic of the ambiance and alleged sanctity of the site on such a day.

This study of the dual site Cathair Crobh Dearg/Dá Chích Anann leaves little doubt: its function "lies in the realm of the ritual and ceremonial, the focus for religious activity", in the words of Coyne (49), and has lied in that realm for thousands of years. Its Christianization obviously changed the form of those rituals. It did not however deprive it from its sacred nature. Even though the probable association with (D)Ana and its mythological tribe was replaced by the veneration of Mary - which is by no means surprising - many rituals remained if not similar at least compatible: Bealtaine is still the favoured day of celebration, even if it is unclear when and how the first association of the site to this specific date was made; Cathair Crobh Dearg provides protection and/or purification to cattle and/or people for one year (from Bealtaine to Bealtaine); the Paps of Anu, which kept their mythical name and were not adapted to the Christian religion, are still part (if not the core and origin) of the sanctity of the place.

This paper relied on archaeological evidence, mythological, folkloric and ethnographic analysis as well as first-hand encounters with contemporary customs. In order to broaden the spectrum of this research, the next step will have to involve other places of interest that would feature compatible symbolism, rituals and archaeological characteristics: comparative studies are often the key to enrich and complete ongoing investigations. This last quotation from Coyne, to whom is owed so much, will give a hint - and actually a bit more - as to where this methodology will take us:

'The City' itself is not dissimilar in size to the phase 2 enclosure at Uisneach, which is $65 \mathrm{~m}$ in diameter, suggested as dating to the Iron Age, and therefore has many other similarities with 'The City', not least of all its mythological affinities, as both sites were the focus of the celebration of the feast of Bealtine, at the beginning of May. (Coyne 50)

Bealtaine was not only a key moment in the Irish year; it was, and to some extent still is, associated with important places disseminated throughout Ireland, North and South of the current border. Some places retain similarities that directly echo ancient beliefs, as is the case 
with Cathair Crobh Dearg. In other instances, those similarities were partially or completely recreated and reshaped for a number of reasons - cultural, commercial, political and/or religious. A comparative field study of the celebration held on the hill of Uisneach on the sixth of May 2017 will perhaps provide an opportunity to defend the theory according to which Bealtaine, and perhaps the other three Irish festivals, may have been as much about space as they were about time.

\section{Notes}

${ }^{1}$ See for instance Guyonvarc'h 29, 84, 127 for versions of Cath Maighe Tuireadh 1 and 2 as well as The Tragic Death of the Children of Tuireann/Oidheadh Chloinne Tuireann; or Keating: "having spent seven years in the north of Scotland, came to Ireland; and, on their coming to land, Monday Bealtaine in the north of Ireland" (213).

${ }^{2}$ See for example NFCS 456: 284-7: "the cattle are driven through the burning embers as in ancient times"; "all the people bring their cattle through the smoke of this fire as it was said it used to preserve them from the fairies working any spell on them" etc; see also NFCS 407: 130; 414: 195; 415: 288.

\section{Works Cited}

Armao, Frédéric. "La Charnière de mai: Beltaine, fête celtique ou fête irlandaise?". Ollodagos. Brussels: Institut des Hautes Études de Belgique, vol. 28, 2013. 61-128.

. "Le pèlerinage de Cathair Crobh Dearg : Coutume séculaire ou acte de résistance?". Conformismes et Résistances. Lille: Université de Lille, 2009. 30 May 2017. http://cecille.recherche.univ-lille3.fr/IMG/pdf/Conformismes_et_resistances-3.pdf.

Collective. "The Folk-Lore of the Months". Journal of Cork Historical and Archaeological Society, II (1896). 157-60. $30 \quad$ May 2017. https://archive.org/stream/journalofcorkhis22cork/journalofcorkhis22cork_djvu.txt.

Coyne, Frank. Islands in the Clouds. An Upland Archaeological Study on Mount Brandon and the Paps, County Kerry. Co. Kerry: Kerry County Council, 2006.

Coyne, Frank and M. Connolly. "Bosom of the Gods: Rescue Excavation on the Western Pap". Archaeology Ireland 16. 1 (2002): 12-5.

Cronin, Dan. In the Shadow of the Paps. Killarney: Crede, Sliabh Luachra Heritage Group, 2001.

DeBhaldraithe, Toma. The Diary of an Irish Countryman (ed. and trans.). Dublin: Mercier Press, 1979 (1970).

Duval, Paul-Marie. Les Dieux de la Gaule. Paris: Payot, 1993 (1957).

Green, Miranda Jane. Dictionary of Celtic Myth and Legend. London: Thames and Hudson, 1992.

Guyonvarc'h, Christian-Joseph. Textes Mythologiques irlandais I (ed. and trans.). Rennes: Ogam-Celticum, 1980.

Keating, Geoffrey. (Comyn, D. and P. Dineen, ed. and trans.) History of Ireland. Cork: University College Cork, 2002 (1634-1636?).

Lysaght, Patricia. "Bealtaine: Irish Maytime Customs and the Reaffirmation of Boundaries". Boundaries and Thresholds. Woodchester: Thimble Press, 1993.

Macalister, Robert Alexander Stewart. Lebor Gabála Erenn (The Book of the Taking of Ireland) (ed. and trans.). Dublin: Irish Text Society, 1941.

MacKillop, James. Dictionary of Celtic Mythology. Oxford: Oxford University Press, 1998.

MacLeod, Sharon Paice. "Early Irish Seasonal Celebrations and gender roles". Proceedings of the Harvard Colloquium 23. Harvard: Harvard University Press, 2003.

MacNeill, Máire. The Festival of Lughnasa. Dublin: Comhairle Bhéaloideas Eireann, 1982 (1962). 
Maignant, Catherine. Histoire et Civilisation de l'Irlande. Paris: Nathan, 1996.

Meyer, Kuno. "The Finn episode from Gilla in Chomded húa Cormaic's poem, 'A Rí richid, réidig dam"". Fianaigecht: Being a Collection of Hitherto Inedited Irish Poems and Tales Relating to Finn and his Fiana. Dublin: Hodges, Figgis \&Co. Ltd., 1910. 47-51. See also: https://www.ucc.ie/celt/published/T303018/.

. "The Boyish Exploits of Finn". 2016 (1901). 30 May 2017. https://www.ucc.ie/celt/published/T303023/index.html.

. "Two Tales about Finn" (ed. and trans.). Revue Celtique, Vol. 14. Paris: Emile Bouillon Libraire-Editeur, 1893. 241-9.

. "The Wooing of Emer by Cú Chulainn”. 2008 (1890). 30 May 2017. http://celt.ucc.ie/published/T301021/index.html.

Murphy, Gerard, ed. Cáel Praises Créide's House in Early Irish Lyrics, Eighth to Twelfth Century. Oxford: Clarendon Press, 1956. 140-6. See also: https://www.ucc.ie/celt/published/G400048/index.html.

Ó Crualaoich, Gearóid. The Book of the Cailleach: Stories of the Wise Woman Healer. Cork, Cork University Press, 2006.

Ó Donovan, John. Ordnance Survey Letters, Kerry. Bray, 1927 (1841).

Ó Grady, Standish Hayes. The Colloquy with the Ancients (ed. and trans.). Cambridge, Ontario: In parentheses Publications, Medieval Irish Series, 1999 (1892).

Ordnance Survey Ireland. Map: http://map.geohive.ie/mapviewer.html 2017.

Rees, Alwyn and Brinley. Celtic Heritage, Ancient Tradition in Ireland and Wales. London: Thames and Hudson, 1988 (1961).

Sjoestedt, Marie-Louise. Dieux et Héros des Celtes. Paris: Presses Universitaires de France, 1940.

Stokes, Whitley. The Irish Ordeals, Cormac's Adventure in the Land of Promise, and the Decision as to Cormac's Sword. (1891) CELT: Corpus of Electronic Texts: a project of University College, Cork. $30 \quad$ May 2017. https://www.ucc.ie/celt/published/T302000.html.

- Three Irish Glossaries, Cormac's Glossary, O' Davren's Glossary, a Glossary to the Calendar of Oingus the Culdee (ed. and trans.). London: Williams and Norgate, 1862.

Tempan, Paul. "Irish Hill and Mountain Names". 30 May 2017. http://mountainviews.ie/features/names/List2010/MVHillList09.pdf

\section{Archival Sources}

National Folklore Collection (main collection, hereafter NFC) 1095: 6-9. Informant 1/Collector: Donnchadh Mac Sheáin Uí Shúilliobháin, Tig Leacaruadh, Ceanmara, Co. Kerry.

NFC 1095: 15-25. Informant 4/Collector: Tadhg Ó Murchadha, An Coireán, Uíbh Ráthach, Co. Kerry.

NFC 1095: 26-28. Informant 5/Collector: Pádraig Réimionn, Killarney, Co. Kerry.

NFC 1095: 29-35. Informant 6/Collector: Eibhlín B. Mhic Conchoille, An Ráth Mór, Co.

Kerry.

NFC 1095: 114-124. Informant 17/Collector: Ned Buckley, Knocknagee, Co. Cork.

NFC 1096: 70-77. Informant 77/ Áine Inghean Mhic Oireachaigh (45), Tulach Uí Chadhain, Moycullen. Co. Galway. Collector: Tomás Breathnach. 
NFC 1096: 312-314. Informant 115/ Barney Donnelly (81), Blundell's Grange, Co. Armagh, May 1947. Collector: Patrick Donnelly (brother).

NFC 1096: 431-434. Informant 144/Collector: Proinnseas Mac a Charraigh, Már-an-Eara, An Craoslach, Co. Donegal.

NFC 1097: 161-164. Informant 183/Collector: Sorca Ní Ruadháin O.S., Cill Mhuire S.N., Áth í, Co. Kildare.

National Folklore Collection Schools' Collection (hereafter NFCS) 407: 1-164. Cloonmackon, Co. Kerry. Teacher: Liam Ó Catháin.

NFCS 414: 49-217. Tubrid More, Co. Kerry. Teacher: Tadhg Ó Ciarmhaich.

NFCS 415: 99-188. Ballyduff, Co. Kerry. Teacher: Brighid, Bean Uí Leathlobhair.

NFCS 441: 178-346. Moyderwell, Co. Kerry. Teacher: Siúracha na Trócaire.

NFCS 452: 1-30. Meentoges, Co. Kerry. Teacher: Eoghan Ó Caoimh. Shrone Beg, Co. Kerry. Teacher: Pádraig Mac Carrthaigh.

NFCS 452: 197-343. Tooreencahill, Co. Kerry. Teacher: Diarmuid Ó Cróinín.

NFCS 453: 83-306. Tooreencahill, Co. Kerry. Teacher: Síghle Ní Shíothcháin.

NFCS 455: 171-289. Killarney, Co. Kerry.Teacher: An tSr. Aodán.

NFCS 456: 161-293. Killarney, Co. Kerry. Teacher: An tSr. M. Déaglán, An tSr. Marie Thérèse.

NFCS 456: 300-402. Knockanes, Co. Kerry. Teacher: Bean Uí Spealáin, Máiréad Ní Laoghaire.

NFCS 697: 200-424. Rathcarran, Co. Meath. Teacher: Caitlín Ní Chonnachtáin.

Received: 06 June 2017 Revised version accepted: 24 July 2017

Frédéric Armao is Associate Professor at the University of Toulon, France. His work mainly focuses on the link between Irish folklore and Celtic mythology, especially in connection with calendar festivals. He has published papers in journals such as Études Irlandaises, Ollodagos and Cosmos for instance and has recently edited two collections of papers, namely Les Nations celtiques et le Monde contemporain (2014) and Croyances contemporaines: regards croisés sur le Monde Anglophone (2017).

frederic.armao@free.fr 